\title{
RETENSI N, Ca DAN P PADA KAMBING YANG DIBERI DEDAK HALUS YANG DIAUTOCLAVE DENGAN LEVEL BERBEDA
}

\author{
E. Pudjihastuti* \\ Fakultas Peternakan Universitas Sam Ratulangi Manado,95115
}

\begin{abstract}
ABSTRAK
Penelitian ini bertujuan adalah untuk mengetahui pengaruh penggunaan dedak halus yang di autoclave dengan level yang berbeda terhadap retensi Nitrogen $(\mathrm{N})$, Kalsium $(\mathrm{Ca})$ dan Fosfor (P) pada ternak kambing.Penelitian ini menggunakan 4 ekor ternak kambing jantan berumur $7-8$ bulan yang berat badan awalnya 8 - $10 \mathrm{~kg}$. Pakan dasar yang digunakan adalah rumput Brachiaria mutica. Hijauantersebut kemudian ditambahkan dengan dedak halus yang di autoclave dengan level yang berbeda, sebagai berikut :

R0 = Rumput Brachiaria mutica

$\mathrm{R} 1=$ Rumput Brachiaria mutica $+10 \%$ dedak halus yang di autoclave

R2 = Rumput Brachiaria mutica $+20 \%$ dedak halus yang di autoclave

$\mathrm{R} 1=$ Rumput Brachiaria mutica $+30 \%$ dedak halus yang di autoclave

Penelitian ini menggunakan metode eksperimen berdasarkan rancangan bujur sangkar latin 4 x 4 dimana ternak berperan sebagai lajur dan metode percobaan sebagai baris, yang dilanjutkan dengan analisis uji jarak berganda Duncan.

Hasil analisis keragaman menunjukkan bahwa perlakuan memberikan pengaruh yang sangat nyata $(p<0,01)$ terhadap konsumsi bahan kering, konsumsi dan retensi $\mathrm{N}$, konsumsi dan retensi Ca serta konsumsi dan retensi P. Dengan uji jarak berganda Duncan menunjukkan bahwa perlakukan R3 sangat nyata $(\mathrm{p}<0,01)$ lebih tinggi dari perlakuan R2, R1 dan R0 terhadap konsumsi dan retensi $\mathrm{N}, \mathrm{Ca}$ dan $\mathrm{P}$.

Dari hasil penelitian ini dapat disimpulkan bahwa penggunaan dedak halus yang di autoclave sampai dengan level $30 \%$ dapat meningkatkan retensi $\mathrm{N}, \mathrm{Ca}$ dan $\mathrm{P}$ pada ternak kambing.
\end{abstract}

*Jurusan Nutrisi dan Makanan Ternak

\author{
Kata kunci : Dedak halus, Autoclave, Retensi, \\ kambing
}

\section{ABSTRACT}

RETENTION OF $N$, $C a$ and $P$ in GOAT GIVEN FINE BRAN THAT OUTOCLAVED WITH DIFFERENT LEVEL. The aim of this study was to determine the effect of autoclaved fine bran use at different levels on the retention of nitrogen $(\mathrm{N})$, calcium $(\mathrm{Ca})$ and phosphorus $(\mathrm{P})$ in goats. This study used four goats at age of 7-8 months old with body weight of $8-10 \mathrm{~kg}$. Basic feed used was Brachiaria mutica grass, which added with autoclaved fine bran at different levels, as follows:

$\mathrm{R} 0=$ Brachiaria mutica grass

$\mathrm{R} 1=$ Brachiaria mutica grass $+10 \%$ autoclaved fine bran

$\mathrm{R} 2=$ Brachiaria mutica grass $+20 \%$ autoclaved fine bran

$\mathrm{R} 1=$ Brachiaria mutica grass $+30 \%$ autoclaved fine bran

This study used an experimental method based on the $4 \times 4$ Latin square design, where livestock served as row and experimental method as a line, followed by Duncan's multiple range test analysis.

Results of analysis of variance showed that the treatment effect is highly significant ( $p$ $<0.01)$ on dry matter intake, consumption and retention of $\mathrm{N}$, consumption and retention of $\mathrm{Ca}$ and P. With Duncan's multiple range test showed that the treatment R3 was higher ( $p$ $<0.01)$ than treatments of $\mathrm{R} 2, \mathrm{R} 1$ and $\mathrm{R} 0$ on consumption and retention of $\mathrm{N}, \mathrm{Ca}$ and $\mathrm{P}$.

From these results, it can be concluded that the use of autoclaved fine bran up to $30 \%$ can improve the retention of $\mathrm{N}, \mathrm{Ca}$ and $\mathrm{P}$ in goats.

\section{Keywords: Fine bran, Autoclave, Retention, Goat}




\section{PENDAHULUAN}

Ketersediaan pakan baik kualitas maupun kuantitasnya adalah merupakan masalah bagi produksi ternak ruminansia. Karena itu diperlukan usaha dengan memanfaatkan pakan asal limbah yang murah harganya serta tidak bersaing dengan kebutuhan manusia. Upaya penyediaan pakan ini lebih di arahkan pada keseimbangan zat - zat makanan sesuai dengan kebutuhan ternak.

Dedak halus merupakan hasil sampingan yang diperoleh dari hasil ikutan penggilingan padi dengan mesin pengasah pertama. Dedak halus pada umumnya digunakan sebagai bahan makanan penguat untuk ternak ruminansiakarena mengandung energi, protein dan vitamin yang cukup tinggi dan memberikan rasa enak bagi ternak. Namun penggunaannya dalam ransum dibatasi karena dedak halus mengandung fitat-fosfor dan asam fitat yang tinggi. Fitat merupakan zat yang tidak dapat dicerna dalam tubuh hewan, selain itu mempunyai kemampuan chelate yang memungkinkan mengikat mineral-mineral lain seperti $\mathrm{Ca}, \mathrm{Mg}, \mathrm{Fe}$ dan $\mathrm{Cu}$. Fitat juga mengikat protein melalui pembentukan kompleks fitat, sehingga protein menjadi tidak tercerna (Manchester, 1992).

$\mathrm{Ca}$ dan $\mathrm{Fe}$ adalah mineral makro yang sangat esensial dibutuhkan oleh ternak. Tersedianya fosfor dari sumber tanaman memberikan dampak yang kurang menguntungkan, karena 50 persen dari $\mathrm{P}$ tampil dalam bentuk asam fitat yang sukar dicerna serta merupakan faktor antinutrisi. Fitat dapat menurunkan absorbsi Ca dengan jalan bersenyawa dengan $\mathrm{Ca}$ di dalam saluran usus membentuk garam yang tidak larut, sehingga dikeluarkan sebagai feses (Tillmandkk, 2001).

Proses pemanasan dengan autoclave adalah suatu proses pemanasan dengan menggunakan suhu dan tekanan yang tinggi, dimana proses pemanasan ini dimaksudkan untuk meningkatkan daya cerna bahan makanan. Pemecahan kompleks fitat yang mengikat $\mathrm{P}, \mathrm{Ca}$ dan $\mathrm{P}$, diharapkan dapat dilakukan dengan proses pemanasan.

Untuk meningkatkan daya cerna, maka dedak halus dipanaskan dengan menggunakan autoclave sehingga dapat membuka dinding sel dari dedak halus menjadi zat-zat yang lebih sederhana dan mudah di cerna. Dengan menggunakan dedak halus yang di autoclave, diharapkan akan meningkatkan kemampuan ternak kambing untuk mencerna zat-zat makanan dalam ransum sekaligus akan meningkatkan retensi makanan dalam tubuh ternak. Berdasarkan uraian diatas, maka telah dilakukan penelitian untuk melihat level yang terbaik untuk penggunaan dedak halus yang di autoclave terhadap retensi $\mathrm{N}, \mathrm{Ca}$ dan $\mathrm{P}$ pada ternak kambing. 


\section{MATERI DAN METODE PENELITIAN}

\section{Ternak dan Manajemen Percobaan}

Penelitian ini menggunakan 4 ekor kambing jantan yang berumur 7-8 bulan, dengan berat badan $8-10 \mathrm{~kg}$. Kandang yang digunakan dalam penelitian ini adalah kandang individu dengan luas 1 x $0,55 \mathrm{~m}$, dan tinggi dari atas tanah $0,5 \mathrm{~m}$. Kandang dilengkapi dengan tempat makan dan tempat minum serta setiap ternak dilengkapi dengan tempat penampungan urine dan feses. Penempatan ternak kambing dalam kandang dan perlakuan dilakukan secara acak (tabel1).

Tabel 1. Bagan Percobaan Ternak Kambing dan Perlakuan

\begin{tabular}{c|c|c|c|c}
\hline \multirow{2}{*}{ Periode } & \multicolumn{4}{|c}{ Ternak Kambing } \\
\cline { 2 - 5 } & 1 & 2 & 3 & 4 \\
\hline I & R0 & R1 & R2 & R3 \\
II & R2 & R3 & R1 & R0 \\
III & R1 & R0 & R3 & R2 \\
IV & R3 & R2 & R0 & R1 \\
\hline
\end{tabular}

Penelitian berlangsung selama 60 hari, yang terdiri dari 40 hari masa adaptasi dan 20 hari masa pengambilan data.

\section{Ransum Percobaan}

Formasi ransum yang diberikan adalah

R0 = Rumput Brachiaria mutica

$\mathrm{R} 1=$ Rumput Brachiaria mutica $+10 \%$ dedak halus yang di autoclave
$\mathrm{R} 2=$ Rumput Brachiaria mutica $+20 \%$ dedak halus yang di autoclave $\mathrm{R} 1=$ Rumput Brachiaria mutica $+30 \%$ dedak halus yang di autoclave Komposisi zat - zat makanan dari ransum yang diberikan dapat dilihat pada tabel 2, sedangkan komposisi zat - zat makanan dari masing - masing ransum perlakuan dapat dilihat pada tabel 3.

Tabel 2. Komposisi zat - zat makanan dari Brachiaria mutica, Dedak Halus tanpa Autoclave dan Dedak Halus yang di Autoclave

\begin{tabular}{l|r|r|r}
\hline $\begin{array}{c}\text { Zat - Zat } \\
\text { Makana } \\
\mathrm{n}\end{array}$ & $\begin{array}{c}\text { Brachiari } \\
\text { a Mutica }\end{array}$ & $\begin{array}{c}\text { Dedak } \\
\text { tanpa di } \\
\text { Autoclav } \\
e\end{array}$ & $\begin{array}{c}\text { Dedak } \\
\text { yang di } \\
\text { Autoclav } \\
e\end{array}$ \\
\hline Protein & 13,25 & 8,14 & 8,60 \\
kasar & & & \\
Serat & 27,40 & 29,54 & 29,47 \\
kasar & 3,00 & 9,40 & 8,80 \\
Lemak & 10,24 & 17,50 & 17,45 \\
Abu & 0,40 & 0,05 & 0,10 \\
Ca & 0,16 & 0,87 & 0,86 \\
P & & 3680,69 & 3561,18 \\
GE(kal/kg & 3300 & \\
\hline
\end{tabular}

Tabel 3. Komposisi zat - zat makanan masing - masing ransum percobaan

\begin{tabular}{|c|c|c|c|c|}
\hline Bahan & \multicolumn{4}{|c|}{ Perlakuan } \\
\hline \multirow{5}{*}{$\begin{array}{l}\text { Brachiaria } \\
\text { mutica } \\
\text { Dedak } \\
\text { halus } \\
\text { Yang } \\
\text { diautoclav } \\
e\end{array}$} & R0 & $\mathrm{R} 1$ & R2 & R3 \\
\hline & Rest & Rest & Rest & Rest \\
\hline & & & & \\
\hline & - & 10 & 20 & 30 \\
\hline & \multicolumn{4}{|c|}{ Persen (\%) } \\
\hline Protein & 13,2 & 12,75 & 12,23 & 11,73 \\
\hline kasar & 5 & & & \\
\hline Serat kasar & 27,4 & 27,61 & 27,81 & 28,02 \\
\hline Lemak & 3,00 & 3,58 & 4,16 & 4,74 \\
\hline
\end{tabular}




\begin{tabular}{l|r|r|r|r}
\hline Abu & 10,2 & 10,97 & 11,68 & 12,41 \\
& 4 & & & \\
\hline $\mathrm{Ca}$ & 0,40 & 0,37 & 0,34 & 0,31 \\
\hline $\mathrm{P}$ & 0,16 & 0,23 & 0,30 & 0,37 \\
\hline $\mathrm{GE}$ & 3300 & 3326,1 & 3352,2 & 3378, \\
$(\mathrm{kal} / \mathrm{kg})$ & & 2 & 4 & 35 \\
\hline
\end{tabular}

Ket : Dihitung berdasarkan tabel 2

\section{Rancangan Percobaan}

Penelitian ini menggunakan metode eksperimen berdasarkan rancangan bujur sangkar latin $4 \times 4$, dimana ternak percobaan berperan sebagai lajur dan periode percobaan sebagai baris. Untuk mengetahui sejauh mana satu perlakuan berbeda nyata dengan perlakuan yang lainnya, analisis dilanjutkan dengan Uji jarak berganda Duncan menurut petunjuk Steel dan Torrie (!991).

\section{Pemberian Ransum}

Sebelum percobaan dimulai, ternak kambing diberi obat cacing untuk menghilangkan pengaruh parasit usus. Hijauan diberikan secara ad libitum pada waktu periode pendahuluan. Selain perlakuan R0, pemberian rumput pada ternak diberikan sesudah pemberian dedak halus yang di autoclave. Pada periode pengumpulan data, ternak hanya diberikan makanan sebanyak $80 \%$ dari jumlah yang dikonsumsi pada masa pendahuluan.

\section{Pengumpulan Data}

Waktu yang diperlukan terdiri atas 4 periode, dimana setiap periode terdiri atas 15 hari yang terdiri dari 10 hari masa pendahuluan dan 5 hari masa pengumpulan data. Pengambilan data untuk feses dan urine dilakukan dengan metode koleksi total selama 1x24 jam. Feses ditimbang berat segarnya kemudian dikeringkan. Urine setelah ditimbang diambil 5\%, kemudian ditetesi dengan $\mathrm{H}_{2} \mathrm{SO}_{4}$.

\section{Parameter Penelitian}

Parameter yang diukur dalam penelitian ini adalah konsumsi bahankering, konsumsi dan retensi $\mathrm{N}$, konsumsi dan retensi $\mathrm{Ca}$, serta konsumsi dan retensi $\mathrm{P}$.

Penetuan retensi $\mathrm{N}, \mathrm{Ca}$ dan $\mathrm{P}$ ransum untuk masing-masing perlakuan dihitung berdasarkan petunjuk Maynard dan Loosly (1969).

$$
\mathrm{R}=\frac{\mathrm{I}-\mathrm{F}-\mathrm{U}}{\mathrm{I}} \times 100 \%
$$

$\mathrm{I}=$ Jumlah zat makanan yang dikonsumsi

$\mathrm{F}=$ Jumlah zat makanan yang terdapat dalam feses

$\mathrm{U}=$ Jumlah zat makanan yang terdapat dalam urine

Konsumsi N (g) bahan kering, diperoleh dari perkalian antara jumlah konsumsi ransum lekor/hari dengan kandungan protein ransum.

Konsumsi Ca (g) bahan kering, diperoleh dari perkalian antara jumlah konsumsi $\mathrm{Ca}$ ransum/ekor/hari dengan kandungan $\mathrm{Ca}$ ransum.

Konsumsi P (g) bahan kering, diperoleh dari perkalian antara jumlah konsumsi $\mathrm{P}$ ransum/ekor/hari dengan kandungan $\mathrm{P}$ ransum. 


\section{HASIL DAN PEMBAHASAN}

Hasil dari pengaruh perlakuan terhadap konsumsi bahan kering ransum dapat dilihat pada tabel 4 .

Tabel 4. Konsumsi bahan kering ransum (gram/ekor/hari)

\begin{tabular}{c|c|c|c|c}
\hline \multirow{2}{*}{$\begin{array}{c}\text { Peri } \\
\text { ode }\end{array}$} & \multicolumn{4}{|c}{ Ternak Kambing } \\
\cline { 2 - 5 } & R0 & R1 & R2 & R3 \\
\hline I & 226,3 & 246,8 & 263,6 & 285 \\
II & 240,4 & 260,8 & 279,1 & 298,3 \\
III & 258,8 & 278,6 & 297,7 & 317,9 \\
IV & 293,5 & 314,1 & 334 & 355 \\
\hline Jumlah & 1019 & 1160,3 & 1174,4 & 1256,2 \\
Rataan & 254,75 & 275,075 & 293,60 & 314,050 \\
& $0^{\mathrm{a}}$ & $\mathrm{b}$ & $0^{\mathrm{c}}$ & $\mathrm{d}$ \\
\hline
\end{tabular}

Keterangan : Beda huruf pada baris yang sama menunjukkan perbedaan yang sangat nyata $(\mathrm{p}<0,01)$

Konsumsi bahan kering ransum bervariasi antara $254,750-314,050 \mathrm{~g}(2,83-$ $3,48 \%$ dari berat badan). Jumlah konsumsi bahan kering tersebut berada pada kisaran kebutuhan ternak kambing menurut tabel NRC (1981), yaitu sekitar $2-3 \%$ dari berat badan. Hal ini memperlihatkan bahwa konsumsi bahan kering meningkat oleh adanya penambahan dedak halus yang di autoclave.

Analisis keragaman menunjukkan bahwa peningkatan level dedak halus yang diautoclave memberikan pengaruh yang sangat nyata $(\mathrm{p}<0,01)$ terhadap konsumsi bahan kering.
Uji jarak berganda Duncan memperlihatkan bahwa perlakuan R3 sangat nyata $(\mathrm{p}<0,01)$ lebih tinggi dari perlakuan R2, R1 dan R0. Selanjutnya perlakuan R2 sangat nyata $(p<0,01)$ lebih tinggi dari perlakuan R1 dan R0, dan perlakuan R1 berbeda sangat nyata $(\mathrm{p}<0,01)$ lebih tinggi dari perlakuan R0 terhadap konsumsi bahan kering.

Rendahnya konsumsi bahan kering pada perlakuan R0 dibandingkan dengan perlakuan R1, R2 dan R3 diduga disebabkan karena meningkatnya kadar asam asetat dalam darah, sehingga menurunkan konsumsi bahan kering. Hal ini sejalan dengan pendapat Tillman $d k k(2001)$, bahwa makanan yang mengandung hijauan kasar akan meningkatkan kadar asam asetat darah, yang pada gilirannya akan menurunkan konsumsi bahan kering.

Peningkatan konsumsi bahan kering pada perlakuan R1, R2 dan R3 sejalan dengan peningkatan penggunaan level dedak halus yang di autoclave, dan hal ini diduga disebabkan oleh meningkatnya palatabilitas makanan karena adanya proses pemanasan (autocalve). Hal ini sejalan dengan pendapat Tan Wong dan de Lumen (1984), bahwa pemanasan dapat mengurangi antinutrisi sehingga dapat meningkatkan palatabilitas bahan makanan. Zat antinutrisi juga dapat dihilangkan sebagian atau seluruhnya melalui proses perebusan, pemanasan 
dengan oven dan autoclave (Sukorharsoyo), 1984). Selanjutnya Samosir (1986) melakukan penelitian dengan pemanasan melalui autoclave, yang hasilnya adalah jauh lebih baik dari pemanasan lainnya.

Hasil dari pengaruh perlakuan terhadap konsumsi dan retensi $\mathrm{N}$ dapat dilihat pada tabel 5 .

Tabel 5.Konsumsi dan Retensi N

\begin{tabular}{c|c|l|l|l|l}
\hline \multirow{2}{*}{$\begin{array}{c}\text { Perl } \\
\text { akua } \\
\mathrm{n}\end{array}$} & Konsum & \multicolumn{3}{|c|}{ N yang keluar } & \\
\cline { 3 - 5 }$(\mathrm{g})$ & si $(\mathrm{g})$ & $\begin{array}{l}\text { Feses } \\
(\mathrm{g})\end{array}$ & $\begin{array}{l}\text { Urin } \\
\mathrm{e}(\mathrm{g})\end{array}$ & $\begin{array}{l}\text { Tota } \\
\mathrm{l}(\mathrm{g})\end{array}$ & $\begin{array}{l}\text { Reten } \\
\text { si }(\%)\end{array}$ \\
\hline $\mathrm{R} 0$ & 38,74 & 14,51 & 10,2 & 24,7 & 35,18 \\
& $5^{\mathrm{a}}$ & 8 & 23 & 41 & $3^{\mathrm{a}}$ \\
$\mathrm{R} 1$ & 40,54 & 13,89 & 9,30 & 23,1 & 43,14 \\
& $8^{\mathrm{b}}$ & 3 & 0 & 93 & $0^{\mathrm{b}}$ \\
$\mathrm{R} 2$ & 42,10 & 13,19 & 8,12 & 21,3 & 4938 \\
& $7^{\mathrm{c}}$ & 0 & 8 & 18 & $0^{\mathrm{c}}$ \\
$\mathrm{R} 3$ & 43,90 & 11,09 & 7,45 & 18,5 & 56,96 \\
& $0^{\mathrm{d}}$ & 5 & 5 & 50 & $3^{\mathrm{d}}$ \\
\hline
\end{tabular}

Keterangan: Beda huruf pada kolom yang sama menunjukkan perbedaan yang sangat nyata $(\mathrm{p}<0,01)$

Angka konsumsi protein kasar bervariasi antara 38,745-43,900 g, dimana angka ini berada pada kisaran seperti yang dikemukakan oleh NRC (1981), yaitu pakan ternak kambing dengan berat badan 10-20 $\mathrm{kg}$ membutuhkan protein 41-60 $\mathrm{g}$ protein/ekor/hari.

Analisis keragaman menunjukkan bahwa meningkatnya level dedak halus yang diautoclave memperlihatkan pengaruh yang sangat nyata $(p<0,01)$ terhadap konsumsi protein kasar. Uji lanjut jarak berganda Duncan, ternyata bahwa perlakuan R3 sangat nyata $(\mathrm{p}<0,01)$ lebih tinggi dari perlakuan R2, R1 dan R0. Selanjutnya perlakuan R2 sangat nyata $(\mathrm{p}<0,01)$ lebih tinggi dari perlakuan R0 terhadap konsumsi protein kasar. Rendahnya konsumsi protein kasar pada perlakuan R0, disebabkan karena rendahnya konsumsi bahan kering pada perlakuan R0. Peningkatan konsumsi protein pada peralkuan R1, R2 dan R3 seiring dengan peningkatan konsumsi bahan kering.

Rataan retensi N (tabel 5) memperlihatkan peningkatan retensi $\mathrm{N}$ pada perlakuan R1, R2 dan R3. Hal ini seiring dengan meningkatnya penggunaan dedak halus yang di autoclave. Analisis keragaman menunjukkan bahwa dengan perlakuan tersebut, memberikan pengaruh yang sangat nyata $(p<0,01)$ terhadap retensi nitrogen. Uji lanjut jarak berganda Duncan menunjukkan bahwa retensi $\mathrm{N}$ pada perlakuan $\mathrm{R} 3$ sangat nyata $(p<0,01)$ lebih tinggi dari perlakuan R2, R1 dan R0. Sedangkan perlakuan R2 sangat nyata $(\mathrm{p}<0,01)$ lebih tinggi dari perlakuan R1 dan R0 dan perlakuan R1 sangat nyata $(\mathrm{p}<0,01)$ lebih tinggi dari perlakuan R0. Peningkatan retensi $\mathrm{N}$ pada perlakuan R1, R2 dan R3 sejalan dengan peningkatan penggunaan dedak halus yang di autoclave. Selain itu juga sejalan dengan peningkatan konsumsi bahan kering ransum, dimana semakin tinggi level dedak halus yang diautoclave (30\%) menyebabkan semakin tinggi retensi $\mathrm{N}$. Hal ini terjadi karena adanya proses pemanasan dengan autoclave yang dapat memperbaiki 
kecernaan protein dan memecah kompleks fitat yang mengikat protein, sehingga protein mudah dicerna dan diserap oleh tubuh. Hal ini sesuai dengan pendapat Ekpenyong dan Borches (1978) dan Purnomoadi (2010), bahwa pemanasan akan memperbaiki kecernaan dari protein. Menurut Purnomoadi (2010), pemanfaatan $\mathrm{N}$ yang teretensi di dalam tubuh ternak digunakan untuk memelihara fungsi jaringan dan proses autoclave bertujuan untuk memecah kompleks fitat yang mengikat protein, maka dengan terpecahnya kompleks fitat ini akan meningkatkan daya cerna dari protein , sehingga protein yang keluar lewat urine dan feses semakin kecil. Anggorodi (1979) menyatakan bahwa pemanasan akan meningkatkan daya cerna bahan makanan.

Hasil dari pengaruh perlakuan terhadap konsumsi dan retensi $\mathrm{Ca}$ dapat dilihat pada tabel 6 .

\begin{tabular}{|c|c|c|c|c|c|}
\hline \multirow{2}{*}{$\begin{array}{c}\text { Perl } \\
\text { akua } \\
\mathrm{n} \\
(\mathrm{g})\end{array}$} & \multirow[b]{2}{*}{$\begin{array}{c}\text { Konsu } \\
\text { msi } \\
(\mathrm{g})\end{array}$} & \multicolumn{3}{|c|}{ Ca yang keluar } & \multirow[b]{2}{*}{$\begin{array}{l}\text { Reten } \\
\text { si }(\%)\end{array}$} \\
\hline & & $\begin{array}{c}\text { Feses } \\
(\mathrm{g})\end{array}$ & $\begin{array}{l}\text { Urin } \\
\text { e }(g)\end{array}$ & $\begin{array}{l}\text { Tota } \\
\mathrm{l}(\mathrm{g})\end{array}$ & \\
\hline R0 & $1,172^{\mathrm{a}}$ & 0,495 & $\begin{array}{l}0,05 \\
3\end{array}$ & $\begin{array}{l}0,54 \\
8\end{array}$ & $\begin{array}{l}53,46 \\
3^{\mathrm{a}}\end{array}$ \\
\hline R1 & $1,189^{b}$ & 0,478 & $\begin{array}{l}0,04 \\
3\end{array}$ & $\begin{array}{l}0,52 \\
1\end{array}$ & $\underset{\mathrm{ab}}{56,161}$ \\
\hline R2 & $1,199^{\mathrm{c}}$ & 0,453 & $\begin{array}{l}0,03 \\
5\end{array}$ & $\begin{array}{l}0,48 \\
8\end{array}$ & $\begin{array}{l}58,40 \\
2^{\mathrm{b}}\end{array}$ \\
\hline R3 & $1,216^{\mathrm{d}}$ & 0,385 & $\begin{array}{l}0,03 \\
3\end{array}$ & $\begin{array}{l}0,41 \\
8\end{array}$ & $\begin{array}{l}65,12 \\
5^{\mathrm{d}}\end{array}$ \\
\hline
\end{tabular}

Keterangan: Beda huruf pada kolom yang sama menunjukkan perbedaan yang sangat nyata $(\mathrm{p}<0,01)$

Konsumsi Ca selama penelitian

(tabel 6) bervariasi antara 1,172-1,216 g/ekor/hari. Jumlah konsumsi Ca ini berada pada kisaran standar kebutuhan seperti yang dikemukakan oleh NRC (1981), dimana ternak kambing dengan berat badan 10-20 kg membutuhkan 1-2 g Ca/ekor/hari. Hasil analisis keragaman menunjukkan bahwa perlakuan terhadap konsumsi $\mathrm{Ca}$ memberikan perlakuan yang sangat nyata $(\mathrm{p}<0,01)$. Selanjutnya uji jarak berganda Duncan menunjukkan bahwa perlakuan R3 sangat nyata $(\mathrm{p}<0,01)$ lebih tinggi dari perlakuan R2, R1 dan R0. Selanjutnya perlakuan R2 nyata $(\mathrm{p}<0,05)$ lebih tinggi dari perlakuan R1 dan perlakuan R2 sangat nyata $(p<0,01)$ lebih tinggi dari perlakuan R0 terhadap konsumsi Ca.

Rendahnya konsumsi $\mathrm{Ca}$ pada perlakuan R0 disebabkan oleh rendahnya konsumsi bahan kering, karena konsumsi Camengikuti konsumsi bahan kering. Konsumsi Ca pada perlakuan R1, R2 dan R3 semakin meningkat dengan peningkatan level dedak halusyang di autoclave.

Rataan retensi $\mathrm{Ca}$ (tabel 6) memperlihatkan peningkatan retensi $\mathrm{Ca}$. Dalam analisis keragaman menunjukkan bahwa peningkatan level dedak halus yang di autoclave memberikan pengaruh yang sangat nyata $(\mathrm{p}<0,01)$ terhadap retensi $\mathrm{Ca}$. Uji lanjut jarak berganda Duncan menunjukkan bahwa perlakuan R3 sangat nyata $(\mathrm{p}<0,01)$ lebih tinggi dari perlakuan R2, R1 dan R0. Dan perlakuan R2 tidak 
berbeda nyata $(\mathrm{p}>0,05)$ dengan perlakuan $\mathrm{R} 1$, tetapi perlakuan $\mathrm{R} 2$ berbedanyata ( $\mathrm{p}<0,05)$ lebih tinggi dari perlakuan R0, sedangkan perlakuan R1 tidak berbeda nyata ( $\mathrm{p}>0,05)$ dari perlakuan R0.

Data retensi Ca pada penelitian ini (tabel 6) bervariasi antara 52,463-65,123. Angka retensi tertinggi terdapat pada perlakuan R3 yang diberikan dedak halus yang di autoclave dengan level 30\% yang diikuti berturut-turut oleh perlakuan R2, R1 dan R0. Hal ini disebabkan karena proses autoclave dapat memecahkan kompleks fitat yang mengikat Ca. Singh et.al. (1986) mengemukakan bahwa dedak halus yang di autoclavemenyebabkan tidak efektifnya antinutrisi yang pada akhirnya akan meningkatkan kecernaan dedak halus, kemudian kompleks fitat yang mengikat $\mathrm{Ca}$ akan dipecah dengan prosesautoclave. Pemecahan kompleks fitat ini terjadi dengan pemutusan ikatan rantai atom karbon sehingga Ca terurai dari kompleks fitat, dengan demikian akan meningkatkan daya cerna. Karena itu semakin tinggi penggunaan dedak halus yang di autoclave maka $\mathrm{Ca}$ yang diserap semakin tinggi. Dengan demikian tingginya konsumsi $\mathrm{Ca}$, sementara total protein yang keluar lewat urine dan feses semakin berkurang (Ca yang tertinggal), dalam tubuh semakin meningkat. Hal ini diduga karena semakin tinggi penggunaan level dedak halus yang di autoclave, maka semakin tinggi kemampuan daya cerna bahan makanan.

Hasil dari pengaruh perlakuan terhadap konsumsi dan retensi $\mathrm{P}$ dapat dilihat pada tabel 7 .

Tabel 7. Konsumsi dan retensi $\mathrm{P}$ selama penelitian.

\begin{tabular}{|c|c|c|c|c|c|}
\hline \multirow{2}{*}{$\begin{array}{c}\text { Perl } \\
\text { akua } \\
\mathrm{n} \\
(\mathrm{g})\end{array}$} & \multirow[b]{2}{*}{$\begin{array}{l}\text { Konsum } \\
\text { si }(\mathrm{g})\end{array}$} & \multicolumn{3}{|c|}{$\mathrm{P}$ yang keluar } & \multirow[b]{2}{*}{$\begin{array}{l}\text { Reten } \\
\text { si (\%) }\end{array}$} \\
\hline & & $\begin{array}{c}\text { Feses } \\
(\mathrm{g})\end{array}$ & $\begin{array}{l}\text { Urin } \\
\mathrm{e}(\mathrm{g})\end{array}$ & $\begin{array}{l}\text { Tota } \\
1 \text { (g) }\end{array}$ & \\
\hline R0 & $0,459^{\mathrm{a}}$ & 0,245 & $\begin{array}{l}0,02 \\
3\end{array}$ & $\begin{array}{l}0,26 \\
8\end{array}$ & $\begin{array}{l}35,18 \\
3^{\mathrm{a}}\end{array}$ \\
\hline $\mathrm{R} 1$ & $0,681^{\mathrm{b}}$ & 0,240 & $\begin{array}{l}0,02 \\
0\end{array}$ & $\begin{array}{l}0,26 \\
0\end{array}$ & $\begin{array}{l}43,14 \\
0^{b}\end{array}$ \\
\hline $\mathrm{R} 2$ & $0,893^{\mathrm{c}}$ & 0,218 & $\begin{array}{l}0,01 \\
7\end{array}$ & $\begin{array}{l}0,23 \\
5\end{array}$ & $\begin{array}{l}43,38 \\
0^{c}\end{array}$ \\
\hline R3 & $1,119^{\mathrm{d}}$ & 0,198 & $\begin{array}{l}0,01 \\
4\end{array}$ & $\begin{array}{l}0,21 \\
2\end{array}$ & $\begin{array}{l}56,96 \\
3^{d}\end{array}$ \\
\hline
\end{tabular}

Keterangan: Beda huruf pada kolom yang sama menunjukkan perbedaan yang sangat nyata $(\mathrm{p}<0,01)$

Rataan konsumsi P (tabel 7) selama penelitian bervariasi antara 0,459 - 1,119 g/ekor/hari. Analisis keragaman menunjukkan bahwa perlakuan memberikan pengaruh yang sangat nyata $(\mathrm{p}<0,01)$ terhadap konsumsi P. Dengan uji jarak berganda Duncan maka perlakuan R3 sangat nyata $(\mathrm{p}<0,01)$ lebih tinggi dari perlakuan R2, R1 dan R0, sedangkan perlakuan R2 sangat nyata $(p<0,01)$ lebih tinggi dari perlakuan R1 dan R0 dan perlakuan R1 sangat nyata $(\mathrm{p}<0,01)$ lebih tinggi dari perlakuan R0.

Konsumsi $\mathrm{P}$ pada perlakuan R0 rendah, karena kandungan $\mathrm{P}$ dalam rumput Brachiaria mutica rendah. Hal ini sesuai 
dengan pendapat Aggorodi (1979), bahwa pada umumnya hijauan rendah kadar fosfornya sedangkan butiran tinggi kadar fosfornya. Peningkatan konsumsi $\mathrm{P}$ pada perlakuan R1, R2 dan R3 disebabkan oleh peningkatan level dedak halus yang di autoclave. Disamping itu juga konsumsi $\mathrm{P}$ meningkat sejalan dengan peningkatan konsumsi bahan kering.

Dari rataan retensi $\mathrm{P}$ (tabel 7) memperlihatkan bahwa perlakuan memberikan pengaruh yang sangat nyata ( $p<0,01)$ terhadap retensi P. Selanjutnya uji jarak berganda Duncan menunjukkan bahwa perlakuan R3 berbeda nyata $(\mathrm{p}<0,05)$ dari perlakuan R2 dan perlakuan R3 berbeda sangat nyata $(\mathrm{p}<0,01)$ lebih tinggi dari perlakuan R1 dan R0. Sedangkan perlakuan R1 berbeda sangat nyata $(\mathrm{p}<0,01)$ lebih tinggi dari perlakuan R1 dan R0, dan perlakuan R1 berbeda sangat nyata $(p<0,01)$ lebih tinggi terhadap perlakuan R0.

Peningkatan retensi $P$ pada perlakuan R1, R2 dan R3 ini seiring dengan meningkatnya penggunaan level dedak halus yang di autoclave dan juga mengikuti tingginya konsumsi $\mathrm{P}$ dan rendahnya $\mathrm{P}$ yang hilang lewat urine dan feses. Peningkatan level dedak halus yang di autoclave juga dapat meningkatkan daya cerna dari $\mathrm{P}$ sehingga konsumsi $\mathrm{P}$ semakin meningkat. Menurut Tillman $d k k$ (2001), lebih kurang $50 \%$ fosfor dalam butiran dalam bentuk garam asam fitat, garam - garam ini berupa Ca dan Mg-fitat yang tidak larut. Sedangkan menurut Anison et.al (1995), dedak halus mengandung "Non-Start Polisakarida" yang merupakan faktor antinutrisi. Selanjutnya menurut Singh et.al (1986), proses autoclave dapat memecah fitat sehingga mineral-mineral yang terikat oleh fitat tersebut akan dibebaskan dan mudah dicerna. Dedak halus yang telah di autoclave menyebabkan tidak aktivnya zat antinutrisi dalam bahan makanan, dimana $\mathrm{P}$ yang terkandung dalam dedak halus yang berbentuk fitat akan terpecah oleh adanya pemanasan dengan suhu yang tinggi (proses autoclave).

\section{KESIMPULAN}

Dari hasil penelitian ini dapat disimpulkan bahwa penambahan dedak halus yang diautoclave sampai dengan level $30 \%$ dapat meningkatkan konsumsi dan retensi dari $\mathrm{N}, \mathrm{Ca}$ dan $\mathrm{P}$ pada ternak kambing.

\section{DAFTAR PUSTAKA}

Anison, G., Moughan, P.J and D.V. Thomas. 1995. Nutritive Activity of Soluble Rice Bran Arabinoxylans in Broiler Diets in British Poultry Science. Carfax. ITB. Bandung.

Anggorodi, R. 1979. Ilmu Makanan Ternak Umum. PT. Gramedia. Jakarta. 
Ekpenyong, T.E. dan R.L. Borches. 1978.

Nutritional Aspects of Winged Bean.

Papers Presented in the $1^{\text {at }}$ Internatinal

Symposium the Potential of Winged

Bean. Los Banos. Philipines.

Manchester, L. 1992. The Use of Phytase in Swine and Poultry Diets. A. Paper for Monogastric Nutrition. Dept. of Animal and Poultry Science. Univ. of Saskatoon, Canada.

Maynard, L.A. and J.K. Loosly. 1969. Animal Nutrition. Tata Graw Hill Publishing Company. Ltd. Bombay New Delhi.

NRC. 1981. Nutrient Requirments of Goats.

No 15. National Academy Press. Washington D.C.

Purnomoadi. A. 2010. Pidato Pengukuhan. Konsep Pakan Protein untuk ternak potong di Indonesia yang berwawasan lingkungan.

Samosir. D. 1986. Suatu Study Laboratoris dan Biologis Terhadap Biji Kecipir. Abstrak. Seminar Fakultas Pasca Sarjana. IPB Bogor.

Singh, K.S., R.P. Decklaker, Vali S.K.M. and A. Tunar. 1986. Use of Rice Brain in The Diet of Chicken IFS Profesional Report. No. 22. Workshoop On Swine Poultry Husbandry.
Steel, R.G.D. and J.H. Torrie.1991. Principle and Procedur of Statistic. McGraw Hill, New York.

Sukorharsoyo, P. 1984. Pengaruh Pengolahan dan Tingkat Biji Kecipir Dalam Ransum Terhadap Bobot Saluran Pencernaan dan Bobot Lemak Abdomen Ayam Pedaging. Karya Ilmiah Fakultas Peternakan Universitas Gadjah Mada. Press, Jogyakarta.

Tan Wong and de Lumen. 1984. Relationship of Tannim Levelsand Trypsin Inhibitor Activity with thein vitroProteinDigestibilities of Raw and Heat Treated Winged Bean [Phosphocarpus tetragonolobus (L) DC]. J. Agric and Food Chemistry. 32:819-822

Tillman, A.D.H. Hartadi., Reksohadiprodjo, S., Prawirokoesumo. $S$ dan E. Lebdosoekodjo. 2001. Ilmu Makanan Ternak Dasar. Gadjah Mada University Press. Yogyakarta. 